\title{
Ribosome Maturation Protein SBDS
}

National Cancer Institute

\section{Source}

National Cancer Institute. Ribosome Maturation Protein SBDS. NCI Thesaurus. Code C97769.

Ribosome maturation protein SBDS (250 aa, $\sim 29 \mathrm{kDa}$ ) is encoded by the human SBDS gene. This protein plays a role in ribosome assembly. 